\title{
The Marketing Model and Human Resources Management Strategies to Achieve Competitive Advantage of Grocery Stores
}

\author{
Rohman Williann ${ }^{1}$, Novita Eka Sari ${ }^{2}$, Tona Aurora Lubis ${ }^{3}$, Rizdhianty Savitri $^{4}$ \\ ${ }^{1}$ Universitas Jambi, Jambi Indonesia, $\bowtie$ (e-mail) rohmanwillian@gmail.com \\ 2 Universitas Jambi, Jambi Indonesia, $\bowtie$ (e-mail) ekasari.novita01@yahoo.com \\ ${ }^{3}$ Universitas Jambi, Jambi Indonesia, $₫$ (e-mail) tonalubis@gmail.com \\ ${ }^{4}$ Universitas Jambi, Jambi Indonesia, $\bowtie$ (e-mail) rizdhisavitri@gmail.com
}

\begin{abstract}
Grocery stores in traditional markets in the Province of Jambi are facing an intense competition, especially with increasing number of minimarkets and modern stores. This can lead to the tight competition between retailers. The purpose of this research is to formulate the model of marketing and human resource management strategy to achieve competitive advantage of grocery stores in traditional market of Jambi. The aim of this study is to analyze the influence of marketing strategy, human resources, and competitive advantage on the competitive advantage. This research used mix method (qualitative and quantitative methods) by using the type of sequel explanatory descriptive. This study conducted a survey involving 85 respondents, who were chosen by using quota sampling technique. The results show that marketing strategy (PMS) has a significant effect on the competitive advantage (KB), and human resources (SDM) has a significant effect on the competitive advantage $(\mathrm{KB})$ of grocery stores in traditional market of Jambi. However, human resource has no significant effect to marketing strategy.
\end{abstract}

Keywords: marketing strategy, human resources management, and competitive advantage

\section{Introduction}

Effectively managing business is the key of successful businesses in this competitive era, especially grocery store. The phenomenon of business development or business in Indonesia today has undergone quite a rapid improvement. In this present day, Indonesia has a lot of groceries that spread in over the place in Indonesia, particularly Jambi Province. Facing the competitive era, the grocery store as a kind of business form need to improve and maintain some aspects in management. Two of the aspects are marketing and human resources. Marketing management process and human resources management process are need to attract profitable customers in achieving decent sales number, and also procuring the loyalty of consumers. Marketing as an influencer on others to be able to buy the products, while human resources capacity of a person to work in the business capability.

Grocery store is kind of a small shop, that is generally accessible to the public and local community and market. Most grocery stores are still traditional and conventional in nature, where the buyer cannot take the goods by themselves, because store shelves are not modern, and it delimitate between the seller and the buyer. Grocery stores offer daily routine goods such as: basic food, dried food, cigarettes, toiletries, soap, and many more (wikipedia.com).

Grocery store as a retail businesses currently facing competition in Indonesia. It can be seen, that the stalls and traditional grocery stores slumped, even it disappeared by abandoned buyers. Starting from hypermarkets as super huge market, supermarkets as household provider, and minimarket as the small form of market, to grocery stores that belongs to the traditional market. Nowadays, online household provider like market online is one of the most transformative changes in the field of marketing to have taken place over the past several decades. This is as a 
result of the existence of the manufacturing business development and market opportunities are quite open, as well as the government's attempt to encourage the development of retail business.

The phenomenon indicates that there are many grocery stores in traditional market areas. The ability of grocery stores in the area to survive not in spite of the ability to compete with monotonous shops as well as modern shops like display of the store. Further, the interesting display or setup product, consumers will be interested in the products offered. Display products will stimulate the curiosity of consumers to products that have been arranged in such interesting, then arises a sense of wanting to buy the product. Even though in the beginning the product is not included in the purchase plan. This indicate that grocery stores have competitive advantage.

Septin (2012) described that the strategy of human resources management to achieve competitive advantage through changing in the role of the Human Resources Management which is not an administrative only, but also as a strategic partner, employee champions and agent of change within company. Meanwhile, Dasipah (2007) also described that human resources management strategy to competitive advantage within the company.

Research on the grocery stores, among others, performed by Filipe, Marques, and Salgueiro (2017) that examined customer relationships with grocery stores in all around the world, and find the positive influence of customer satisfaction is the highest part of the grocery customer loyalty program. While research Lombart, Labbe-Pinlon, Hahn, Anteblian, and Louis (2018) find loyal customers of regional grocery stores with local products in France due to an appropriate product placement strategy.

On the other hands, Kasasbeh (2017) indicated the relationship between human resource management with the competitive advantage of the company. Jasim (2014) described that the competitive advantage of a company will be obtained through the improvement of the quality of employees (HR) company.

Ejrami, Nader, and Ahmadian (2016) stated in this competitive era, merchant companies marketing variable of marketing potentials to enhance performance and competitive advantage. Gupta and Maholtra (2016) indicated that a consequence of this era is an innovative marketing by engaging a network with local enterprise.

This research is important and interesting, because this research of the marketing strategy and human resource management to achieve competitive advantage in various types of attempts have been made, but the research at the grocery store in traditional markets is still limited. It raises a research gap research.

\section{Methods}

This research used mix method by using the type of sequel exploratory design. The first phase was qualitative method and quantitative method on the next phase. The qualitative stage consisted of four steps, as follows. First, problem and the potential research object identification. Second, theoretical studies by using phenomenology approach. Third, data collection by using in-depth interview, observation, and documentation. Then it was followed by data analysis using data reduction and analysis conclusion, withdrawal, domain verification, and reflection. The fourth step was to test the hypotheses with the discovery of the indicators and variables of the study.

The next stage was the quantitative method. The first step is determining the quantitative sample from the entire population. This research was conducted by the participation from several grocery stores in province of Jambi. The sample was selected using quota sampling technique. The sample of this research was 85 grocery stores that are in traditional market in Jambi. The 
questionnaire was designed by using 5-point Likert scale. The second step manage primary and secondary data. Furthermore, the third step was descriptive and inferential analysis.

\section{Results and Discussion}

The results discussed in this section are based on the data collected form 85 respondents. All respondents are owners of grocery store in Jambi who were selected by quota sampling technique. Some details of the research respondents are age of the grocery stores owner, ownership type of the grocery stores, age of the grocery stores, and the number of grocery stores' employee. The details of these essentials are shown in the Table 1.

Table 1 The respondents' demographic characteristics

\begin{tabular}{ll}
\hline Characteristics & Percentage (\%) \\
\hline Age: & \\
a. $<31$ years old & $0 \%$ \\
b.31-40 years old & $4.76 \%$ \\
c.41-50 years old & $38.09 \%$ \\
d. 50 years old & $57.14 \%$ \\
\hline Last Education: & \\
a. $<$ Secondary Level & $61.90 \%$ \\
b. D3 & $4.76 \%$ \\
c. S1 & $33.33 \%$ \\
d. S2/S3 & $0 \%$ \\
\hline Age of grocery store: & \\
a. $>10$ years & $80.95 \%$ \\
b. 5-10 years & $9.52 \%$ \\
c. 2 -5 years & $4.76 \%$ \\
d. $<2$ years & $0 \%$ \\
\hline Position of business: & \\
a. Owner and founder & $100 \%$ \\
b. Owner & $0 \%$ \\
c. Manager & $0 \%$ \\
\hline Ownership type: & \\
a. Self-ownership & $66.67 \%$ \\
b. Cooperating & $4.76 \%$ \\
c. Family ownership & $28.57 \%$ \\
\hline Number of Employee: & \\
a. <5 persons & $100 \%$ \\
b. 5-10 persons & $0 \%$ \\
c. $11-20$ persons & $0 \%$ \\
d. $21-30$ persons & $0 \%$ \\
\hline
\end{tabular}

Table 1 shows the structure and characteristics of the sampled grocery stores throughout the area of Jambi. It shows that the majority owners of the grocery stores are of 50 or over 50 years old of age. Many of the grocery stores' owners has been running their businesses for more than ten years. The majority grocery stores' owners are of secondary level education. Most grocery stores in Jambi are run by their own owners and have at most five employees.

The results of the qualitative phase of this research findings variables and indicators on the Table 2 
Table 2 Research variables and indicators

\begin{tabular}{ll}
\hline \multicolumn{1}{c}{ Variables } & \multicolumn{1}{c}{ Indicators } \\
\hline Human Resources Management $\left(\mathrm{X}_{1}\right)$ & (1) Planning (sdm1) \\
& (2) Selection (sdm2) \\
& (3) Training and Development (sdm3) \\
& (4) Performance(sdm4) \\
& (5) Compensation(sdm5) \\
& (6) Maintenance (sdm6) \\
& (7) Managers and Employees relationship (sdm7) \\
& (1) Segmentation (pms1) \\
Marketing Strategy Variable $\left(\mathrm{X}_{2}\right)$ & (2) Market Target (pms2) \\
& (3) Market Position (pms3) \\
Competitive advantage (Y) & (1) Efficiency (kb1) \\
& (2) Uniqueness(kb2) \\
& (3) Cost Advantage (kb3) \\
& (4) Differentiation (kb4)
\end{tabular}

The next phase of the quantitative was using component based structural modeling. Based on the results of this research, the calculated model can be seen in Figure 1.

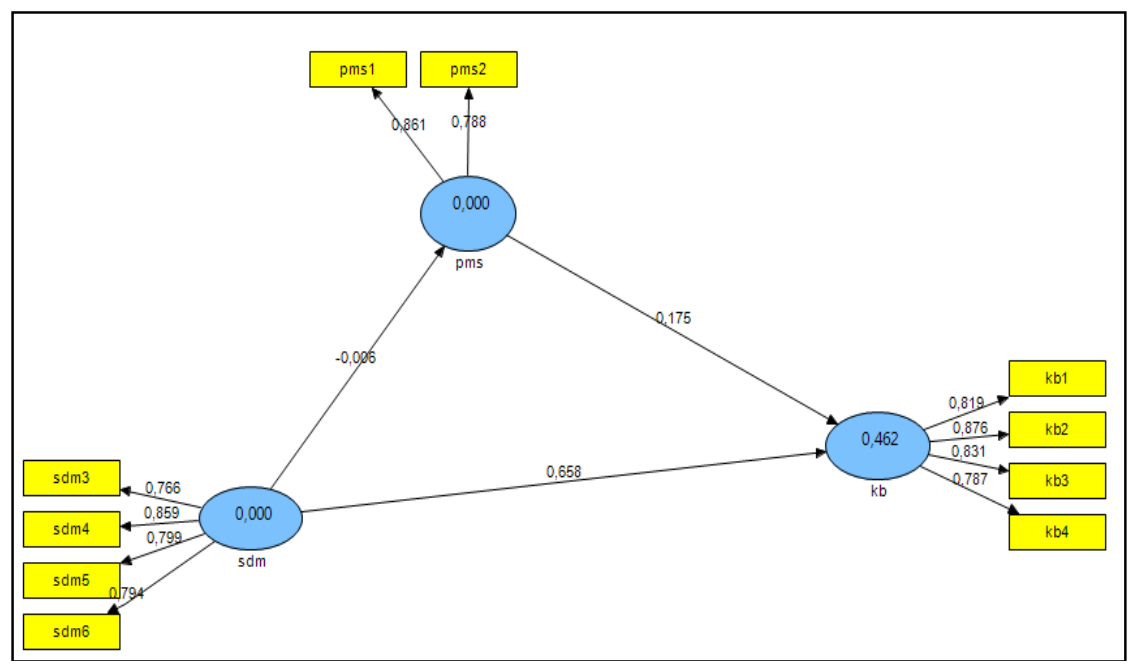

Figure 1 The research model

Figure 1 indicates that marketing strategy variable (PMS) indicator, pms3 has value of loading small factor from point 0.6. It means that marketing strategy (PMS) of grocery stores in the area of traditional markets in the province of Jambi reflected by indicators of market segmentation (PMS1) and market target (PMS2). On the other hands, human resource management strategy variable indicator of human resource planning (SDM1), selection (SDM2) and relationship between managers and employees (SDM7) have values on less than point 0.6. It means that strategy of human resource management in the market area of grocery store in Jambi province can be reflected by indicators of training and development (SDM3), performance (SDM4), compensation (SDM5), and maintenance (SDM6). Whereas competitive 
advantage variable $(\mathrm{KB})$ of these four indicators have values on point 0.6. It means that competitive advantage of the grocery store in the area of traditional market in Jambi province can be reflected by the entire charge indicators. Validity of this study used AVE point and communality:

Table 3 AVE and Communality

\begin{tabular}{ccc}
\hline & AVE & Communality \\
\hline KB & 0.687739 & 0.687739 \\
PMS & 0.675176 & 0.675176 \\
SDM & 0.515903 & 0.515903 \\
\hline
\end{tabular}

Source: PLS Output (2018)

Table 3 shows the value of AVE and communality above point 0.5 for all variables. It means that all variables have the value of the discriminant validity. Reliability in research as well as the consistency of the research instrument is as follows:

Table 4 Reliability coefficient Cronbach alpha and composite reliability

\begin{tabular}{ccc}
\hline & Cronbach Alpha & Composite Reliability \\
\hline KB & 0.849749 & 0.897955 \\
PMS & 0.735775 & 0.804522 \\
SDM & 0.809563 & 0.863671 \\
\hline
\end{tabular}

Source: PLS Output (2018)

Table 4 indicates that the average value of Cronbach alpha and composite reliability for all variables of this study above point 0.70 , or it could be said that all reliability instrument (questionnaire) on this research revealed the "reliability" and tested the establishment, so that it can be used in further research. The bootstrapping results to model can be seen in the following Figure 2.

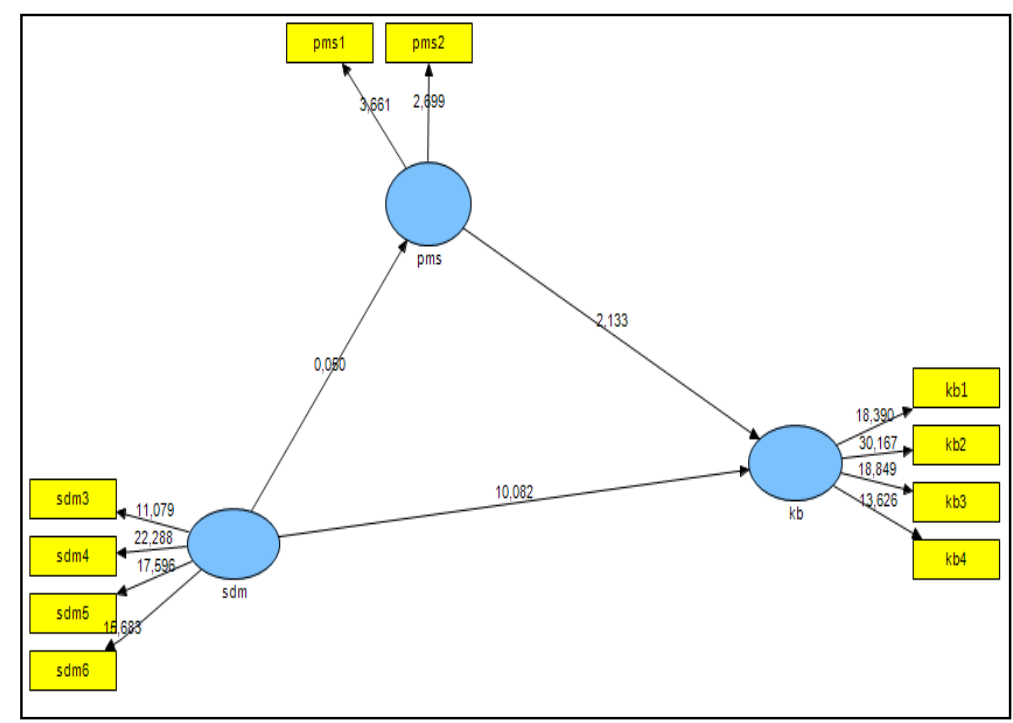

Figure 2 Bootstrapping results to research model

Table 5 shows the influence between the variables in this study. The influence of significance variable can be seen from the $t$ value on point 1.96. Table 5 shows the influence of marketing strategy variable (PMS) to competitive advantage on point 0.17 and significant, and the influence of management human resources variable (HR) to competitive advantage (KB) shows the number on point 0.66 and significant, While the influence of the variable of human resources (HR) management to marketing strategy (PMS) are not significant. 
Table 5 Path coefficients (mean, stdev, t-values)

\begin{tabular}{cccccc}
\hline & $\begin{array}{c}\text { Original } \\
\text { Sample } \\
(\mathrm{O})\end{array}$ & $\begin{array}{c}\text { Sample Mean } \\
(\mathrm{M})\end{array}$ & $\begin{array}{c}\text { Standard Deviation } \\
(\mathrm{STDEV})\end{array}$ & $\begin{array}{c}\text { Standard } \\
\text { Error } \\
(\text { STERR })\end{array}$ & $\begin{array}{c}\text { T Statistics } \\
(\mid \mathrm{O} / \text { STDEV } \mid)\end{array}$ \\
\hline PMS $>$ KB & 0.175209 & 0.172490 & 0.082152 & 0.082152 & 2.132741 \\
SDM -> KB & 0.657632 & 0.660398 & 0.065227 & 0.065227 & 10.082163 \\
SDM -> PMS & -0.006082 & 0.011355 & 0.122078 & 0.122078 & 0.049818 \\
\hline
\end{tabular}

Source: PLS Output (2018)

Results of the analysis show that the marketing strategy (PMS) affecting competitive advantage (KB) of grocery stores in the area of traditional markets in Jambi Province. These results support prior research, such as Ejrami, Nader Salehi, and Ahmadian (2016), Gupta and Maholtra (2016), and Jummaini (2014). Likewise, human resource management (SDM) influences competitive advantage (KB) of grocery stores in the area of traditional markets in Jambi Province. These results support previous research findings, such as Septin (2012) and Dasipah (2007), Kasasbeh (2017), and Jasim (2014).

This paper contains some limitations of research scope because this paper only examined two aspects of management, such as marketing in order to examine the marketing strategy of grocery store in this competitive era, and human resources management. Future research is recommended to add some aspects like financial, operational, and others to their research.

\section{Conclusions}

The purpose of this research is to formulate the model of marketing and human resource management strategy to achieve competitive advantage of grocery stores in traditional market of Jambi. The aim of this study is to analyze the influence of marketing strategy, human resources, and competitive advantage on the competitive advantage.

The model of this study is able to find factors that affect the competitive advantage of grocery stores in the area of traditional markets in Jambi Province Jambi is human resources management and marketing strategy. It can be occurred due to the presence of emotional closeness between customers and traders or employees of the grocery stores.

This study provides evidence that human resources play an important role in the relationship and with customers in business. Emotional relationship will appear because of the long relationships. As the case shown in this study that business relationships that occur between traders and consumers has lasted for a long time. Most grocery stores in this study have already in business for over a decade. The existence of emotional relationship give raise to the buyers' loyalty.

\section{Acknowledgments}

This research paper was supported by some previous researchers. The authors would also like to show our gratitude to the respondents for sharing their pearls of wisdom with us in providing information of this research, particularly all owner of grocery store. The authors are also immensely grateful to Universitas Jambi Research Institution for funding this research.

\section{References}

Agustinus, S., W. (2004). Manajemen Strategik: Pengantar Proses Berpikir Strategik. Jakarta: Binarupa Aksara.

Buchari, A. (2008). Kewirausahawan. Bandung: Alfabeta.

Budi, W., Soetjipto. (2001). Manajemen Sumber Daya Manusia; Sebuah Tinjauan Komprehensif: Usahawan. Jakarta: Lembaga Manajemen FEUI. 
Cruz, M. E. D. L., Jover, A. J. V., \& Gras, J., M., G. (2018). Influence of the entrepreneur's social identity on business performance through effectuation. European Research on Management and Business Economics, 24, 90-96.

Dasipah. (2012). Menganalisis Pelanggan dan Pesaing. Bekasi: Universitas Islam 45.

Dessler, Gary, (2001). Human Resources Management. California: Prentice Hall International Inc.

Ejrami, Nader, \& Salehi. (2016). The effect of marketing capabilities on competitive advantage and performance with moderating role of risk management in importation companies. ProcediaEconomics and Finance, 36, $22-28$.

Filipe, Marques Salgueiro. (2017). Customers' relationship with their grocery store: Direct and moderating effects from store format and loyalty programs. Journal of Retailing and Consumer Services, 37, 78-88.

Gupta, Malhotra. (2016). Marketing Innovation: A Consequence of Competitiveness. Journal of Business Research, 69, 5671-5681.

Harris, Michael. (2000). Human Resource Management. Second Edition. The Dryden Press. USA.

Henry Simamora. (2001). Manajemen Sumber Daya Manusia. $2^{\text {nd }}$ Edition. Yogyakarta: Bagian Penerbitan STIE YKPN.

Enjolras, G., Aubert, M. (2017). Short food supply chain and the issue of sustainability: A case study of French fruit producers. International Journal of Retail and Distortion Management, 2(13).

Ilyuk, V. (2018). Like throwing a piece of me away: How online and in-store grocery purchase channels effect consumer food waste. International Journal of Retailing and Consumer Services, $4(42), 20-30$.

Jassim. (2014). Competitive Advantage Through the Employees. Retrieved from: https://www. researchgate.net/publication/242620997.

Joonas, Mantymaa. (2013). Gaining competitive advantage through quality of services in financial industry. Thesis. Department of Management.

Jummaini. (2014). Pengaruh strategi diferensiasi terhadap keunggulan bersaing pada distro dan butik di kota Lhoksumawe.

Kasasbeh. (2017). Developing a conceptual model for the relationship between human resource management, e-business strategies and competitive advantage. Journal of Internet Banking and Commerce.

Li, G., Shao, S., Zhang., Z (2017). Green supply chain behavior and business performance evidence from China. Technological Forecasting and Social Change Journal.

Lofsten, Hans. (2016). New Technology - based firms and their survival: The Importance of business networks, and entrepreneurial business behaviour and competition. Sagepub Journal in Perspective Local Economy, 31(3).

Lombart, Labbe, P., Hahn, \& A., Louis. (2018). Regional product assortment and merchandising in grocery stores: strategies and target customer segments. Journal of Retailing and Consumer Services, 42, 117-132.

Syakir, S., M. (2003). Prospek dan Tantangan Asuransi Syariah. Paper presented at Sharia Economy Seminar The International Institute of Islamic Thought Indonesia.

Nurhuda, L., Setiawan, B., \& Andriani, D., F. (2017). Supply chain management analysis of potato (Solanum Tuberosum L.) at Ngadas Village, Poncokusumo subdistrict, Malang regency. Jurnal Ekonomi Pertanian dan Agribisnis (JEPA), 1(2).

Ozcan, G., B., Mondragon, A., E., C., Harindranath, G. (2016). Strategic Entry and Operational Integration of Emerging Market Firms: The Case of Cemey, Beko, and Tata Steel in the UK. Journal of Business Research.

Septin. (2012). Strategi Manajemen Sumber Daya Manusia Dalam Meningkatkan Keunggulan Bersaing Perusahaan.

Sofyan, A. (2007). Manajemen Pemasaran. Jakarta: PT Raja Grafindo Persada.

Sofjan, A. (2000). Strategi Manajemen Sumber Daya Manusia. Jakarta: Lembaga Manajemen FEUI.

Straus, Sayles. (1999). Manajemen Personalia Segi Manusia dalam Organisasi. Jakarta: PPM. 
Tshipa, J. (2016). Corporate Governance and Financial Performance: A Study of Companies Listed on The Johannesburg Stock Exchange. Universiteit Van Pretoria Dissertation.

Ujang, S. (2004). Perilaku Kosumen Teori dan Penerapanya dalam Pemasaran. $1^{\text {st }}$ Ed. Bogor: Ghalia Indonesia.

Werther, William, B., Davis, K. (1999). Human Resources and Personnel Management. $8^{\text {th }}$ Edition. McGraw-Hill Inc.

Wheelen, Thomas. L, Hunger, David J. (1999). Strategic Management and Business Policy. Ontario: Addison-Wesley Publishing Company.

William, F., Lawrence, \& R. Jauch. (1999). Manajemen Strategis dan kebijakan Perusahaan. Penerbit Erlangga. Jakarta. 